\title{
コバルト $(\mathrm{III})-\mathrm{EDTA}$ 錯体の放射線分解における溶質濃度および $p \mathrm{H}$ の影響*1
}

\author{
(昭和 39 年 11 月 5 日受理)
}

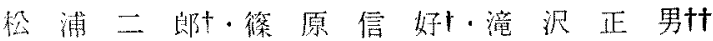

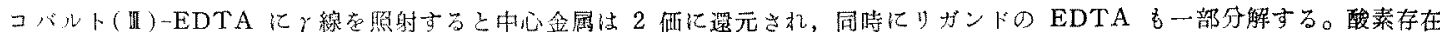

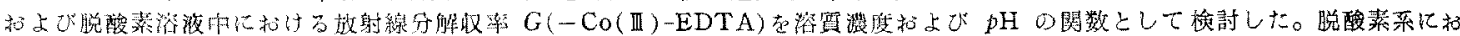

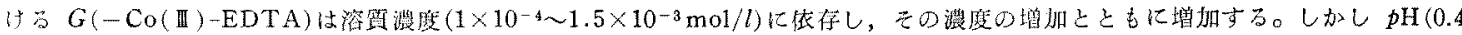

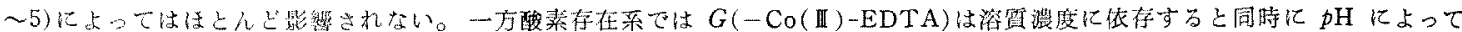

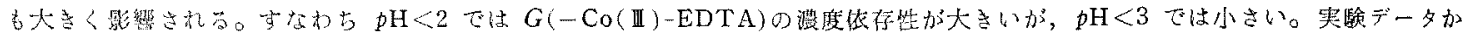

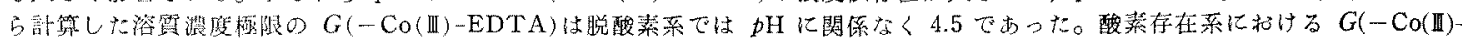

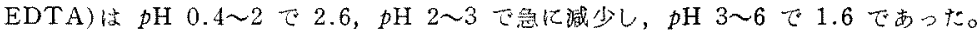

\section{1 序論}

金属キレート化合物の齐薄水溶液に対主るイオン化放射線効果 上コバルト(II)-EDTA の放射線分解の化学量諭的研究をとりあ

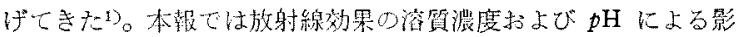

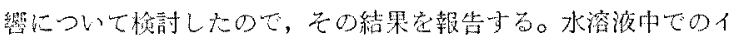
オン化放射線の作用て锥測さ机る溶得の分解収率は $\mathrm{pH}$ の变化に よっているじるしく影留されることはか子り以前名ら知られてい

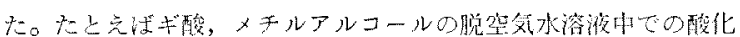

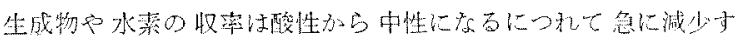

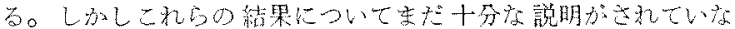

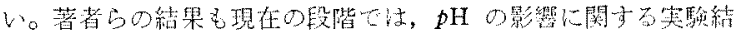
果老十分には説明し得ないけれに゙も，この種の疑問应解浃与る一 つのデータとして報告孛る。

\section{2 実験}

\section{1 照射試料}

コバルト（II)-EDTA は前報》記した方法により合成し，2 问再結晶したものを用いた。3回蒸留水でっった種々の $p \mathrm{H} の$

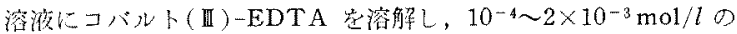

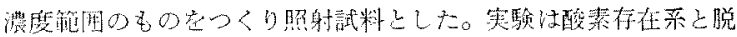
酸装䒺の二つの埸合について行炽い，後者の場台はアルカリ性ピ ロガロール中を汿しな篗素ガスを約 1 時間通じるこににより脱酸 素した。

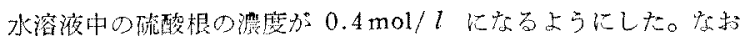

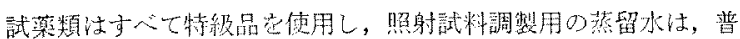

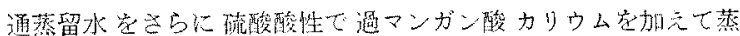
留，さらに水酸化ナトりウム安加えて蒸留したむの袁用いた。

\section{2 装㯰}

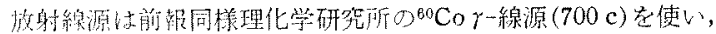

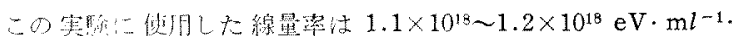

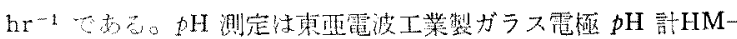
5 A 俌用した。

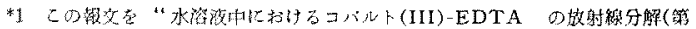

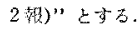

$\dagger$ Niro MATSUURA, Nobuyoshi SHINOHARA 東秀大紫教学学部

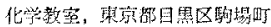

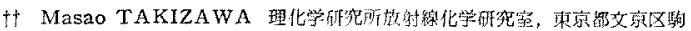
込上要士前朾

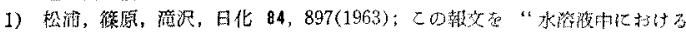

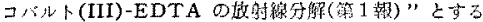

\section{3 その他}

コバルト(II)-EDTA の定量，線量䱣の測定，および分解収率 の求方方などは前報りと同じである。

\section{3 実 験 結 果}

\section{1 酸素存在系における分解收率}

$0.8 \mathrm{~N}$ 硫酸中のコバルト(II)-EDTA の吸収スペクトルおよび

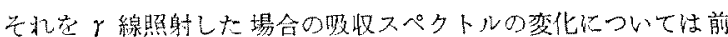
報〉飞報告した。 $p \mathrm{H}$ が大きくなっっても吸收スペクトルに変化は なく, $380 と 535 \mathrm{~m} \mu$ に極大吸収が品る。種々の 卜 (II) -EDTA 溶液照射劣る上この二つの極大吸収は照射線量 ○增加ととも红減少子る。照射後，照射溶液の $\mathrm{pH}$ 飞変化はみら れなかった。種々の浀度のコバルト(四)-EDTA 5.0)老加之一照射し，照射線量上分解量上の関倸它酸素存在系々 ついて求为た。艺の一例として溶留湛度定一定 $\left(10^{-3} \mathrm{~mol} / l\right) \mathrm{K}$

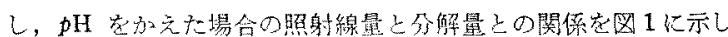

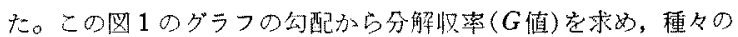

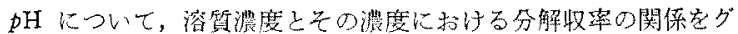

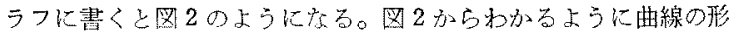

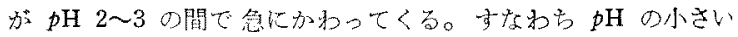

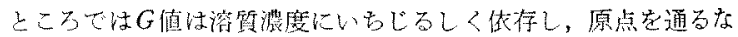
めらかな曲線であるるが $p \mathrm{H}$ の大きいところでは $G$ 值の溶質浱度

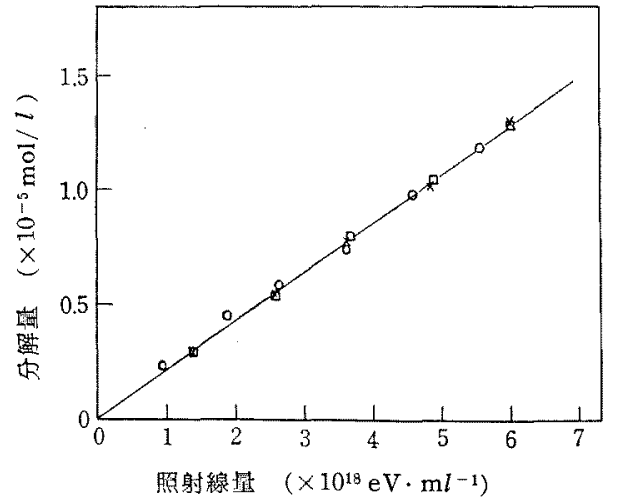

コバルト(II)-EDTAの初笭度: $1.00 \times 10^{-3} \mathrm{~mol} / l$ 酸素存在系

$\square: p \mathrm{H}=1.0, \quad 0: p \mathrm{H}=2.0, \quad x: p \mathrm{H}=3.0$

图 1 稙々のpH に㧍けるコバルト (III)-EDTAの 分解堅七照射線是との関係 


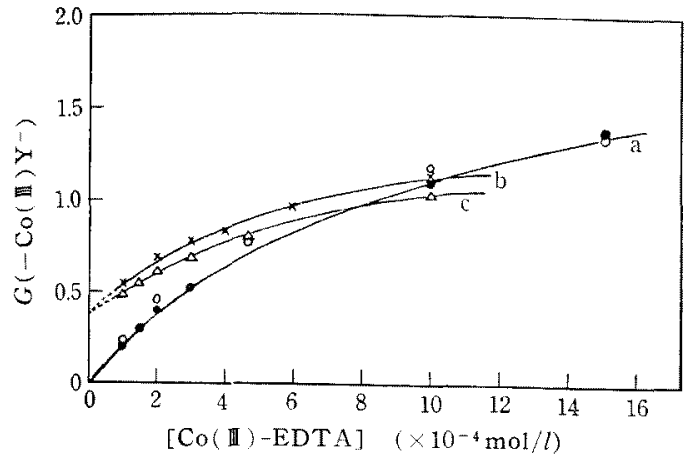

: $p \mathrm{H}=0.4, O: p \mathrm{H}=2.0, \quad \times: p \mathrm{H}=3.0, \triangle: p \mathrm{H}=4.0$

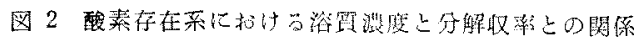

依存性沈がり少なくなる。

\section{2 脱酸素系の分解収率}

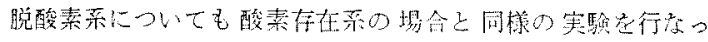
た。種々の $p \mathrm{H}$ に㧍けるコバルト(咕)-EDTA の分解量上照射

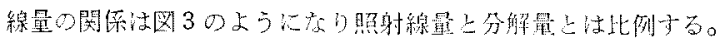

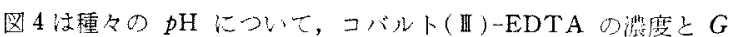

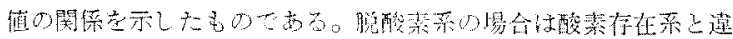

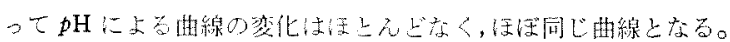

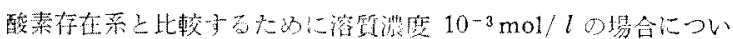

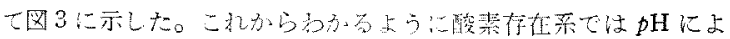

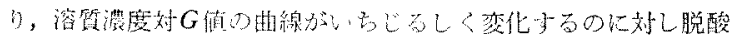

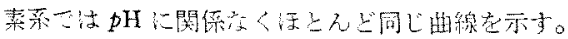

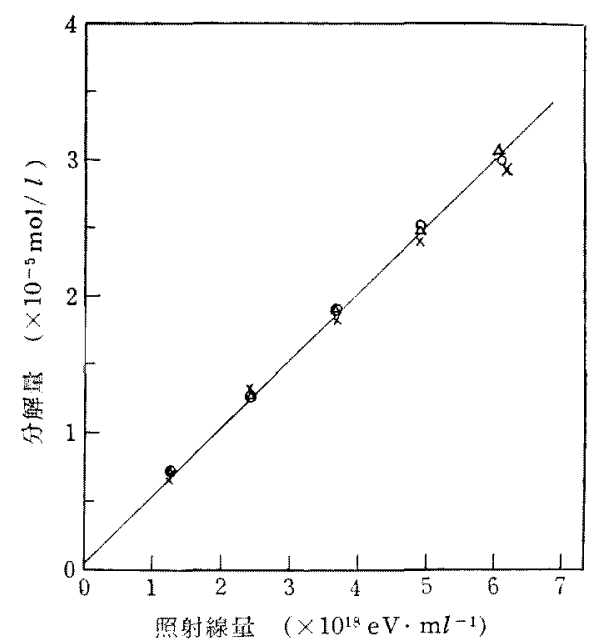

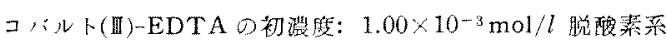

$0: p \mathrm{H}=2.0, \quad x: p \mathrm{H}=3.0, \triangle: p \mathrm{H}=4.0$

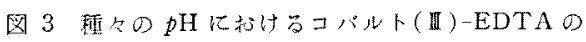

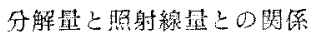

\section{4 考察}

\section{1 無限濃度における分解収率}

コバルト(II)アコ・イオンにケ線老照射すると $\mathrm{Co}^{3+} \rightarrow \mathrm{Co}^{2+}$ ○

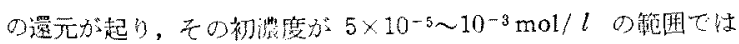

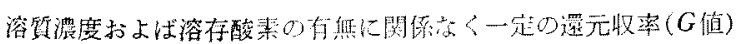

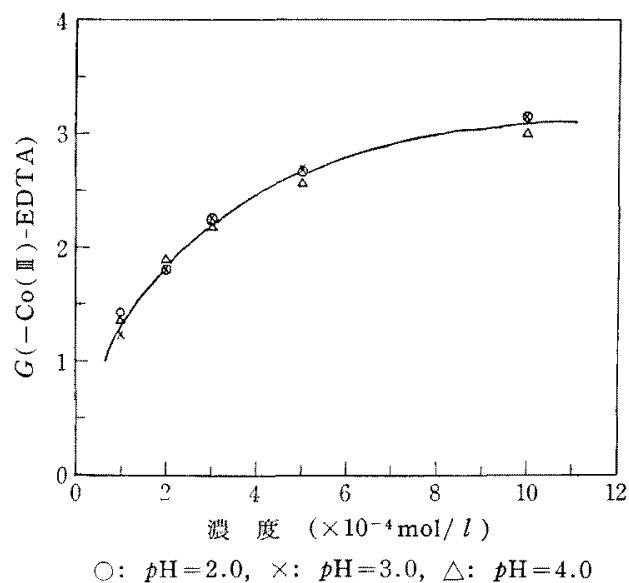

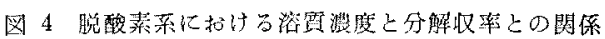

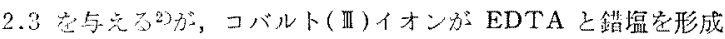

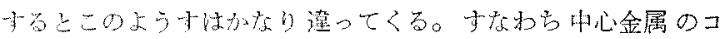

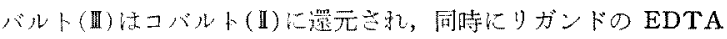

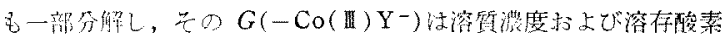

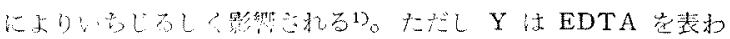

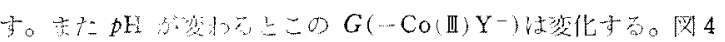

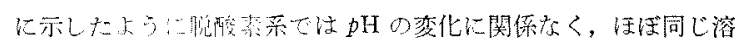

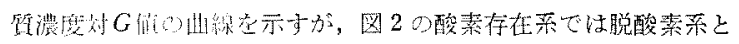

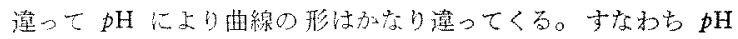

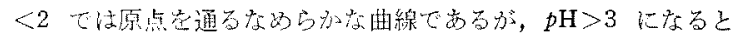

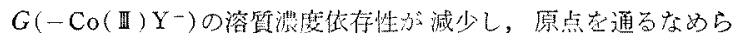

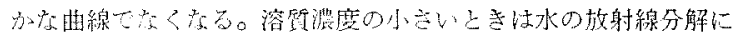

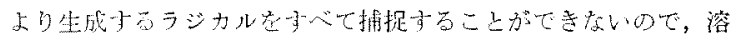

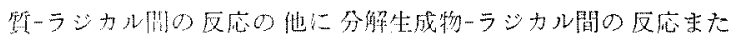

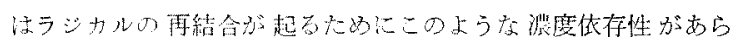

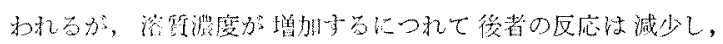

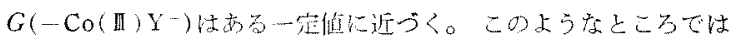

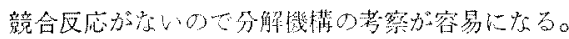

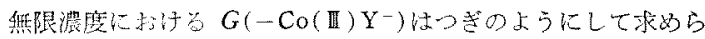

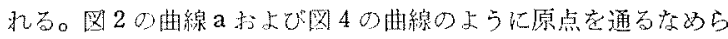

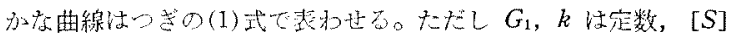

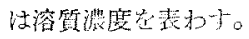

$$
G\left(-\mathrm{Co}(\text { I }) \mathrm{Y}^{-}\right)=\frac{G_{1}}{1+\frac{k}{[S]}}
$$

(1)式在变形古るし(2)武のようになり，G(一[S]のそれぞれの逆数てプロット古ると直線になるのでこれを

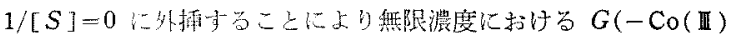

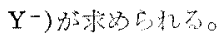

$$
\frac{1}{G\left(-\mathrm{Co}(\mathbb{I I}) \mathrm{Y}^{-}\right)}=\frac{1}{G_{1}}+\frac{k}{G_{1}[S]}
$$

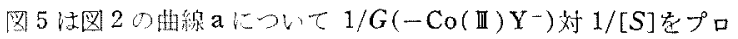
ットしたものである。

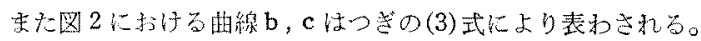
$k, G_{2}$ は定数でる。

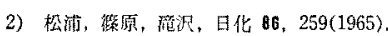




$$
G\left(-\operatorname{Co}(\mathbb{I}) \mathrm{Y}^{-}\right)=G_{2}+\frac{G_{1}}{1+\frac{k}{[S]}}
$$

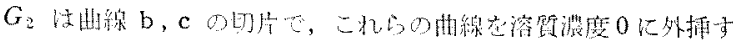

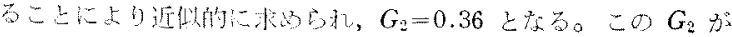

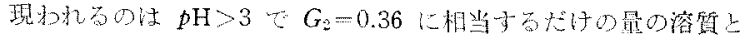

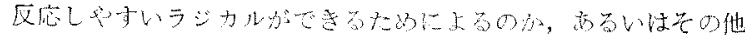

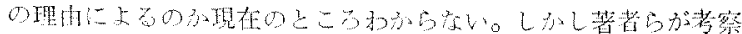

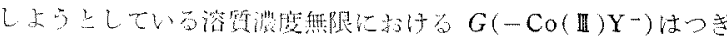

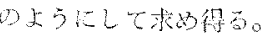

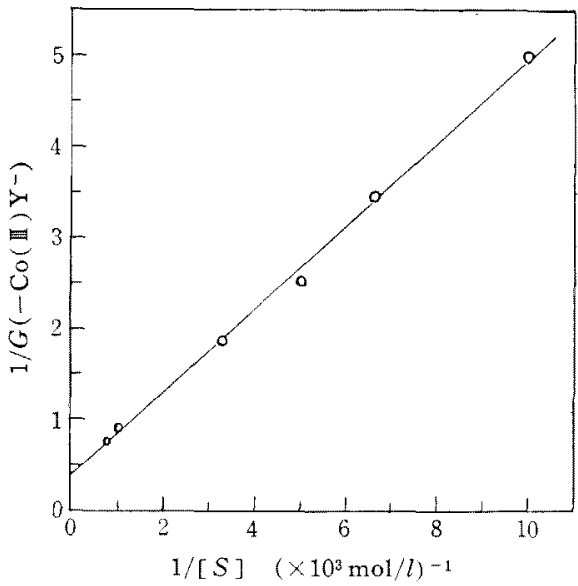

园 $51 / G\left(-\operatorname{Co}(\mathbb{I I}) \mathrm{Y}^{-}\right)$対 $1 /[S] \emptyset \neq f ロ y 卜$

$G_{2}=0.36$ 去(3)式に代入し，变形与をと(4)式の上5に各。

$$
\frac{1}{G\left(-\operatorname{Co}(\mathbb{I I}) \mathrm{Y}^{-}\right)-0.36}=\frac{1}{G_{1}}+\frac{k}{G_{1}[S]}
$$

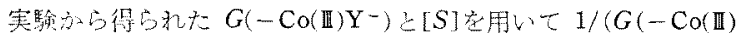

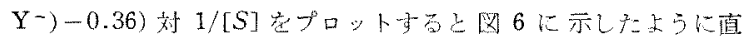

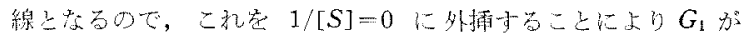

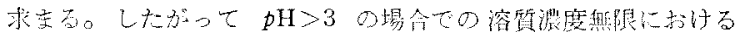
$G\left(-\operatorname{Co}(\right.$ III $\left.) \mathrm{Y}^{-}\right)$注 $G_{1}+G_{2}$ 己学名。

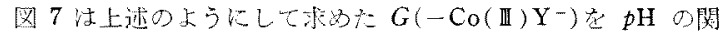
数上して表わしたものてある。

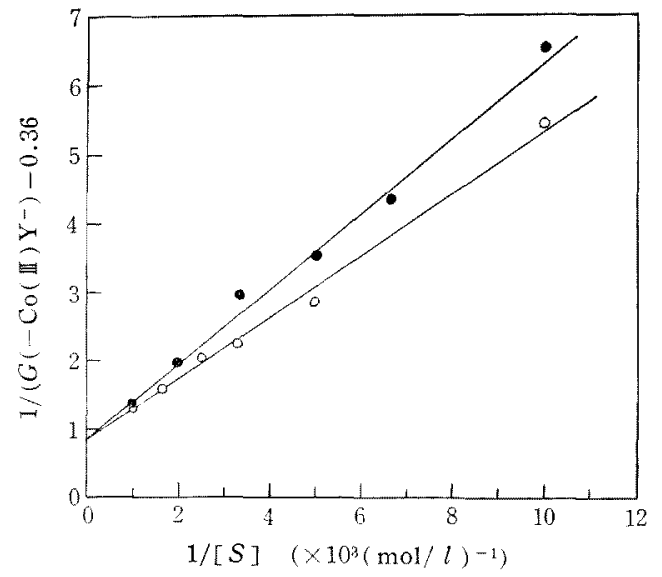

O: 因 2 ○曲線 b,

图 20 腺 $\mathrm{C}$

园 $61 /\left(G\left(-\operatorname{Co}(\mathbb{I I}) \mathrm{Y}^{-}\right)-0.36\right)$ 站 $1 /[S] 0$ プロッ

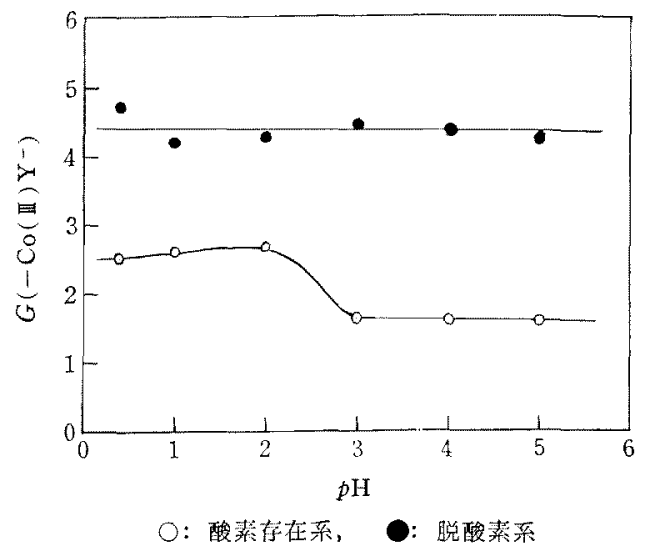

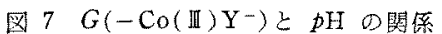

\section{2 分解収宰におよぼす溶存酸素の影響}

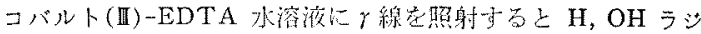
カルはまずりガンドのEDTA 怒攻慗して脱水䕀反応が起り，そ

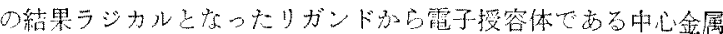

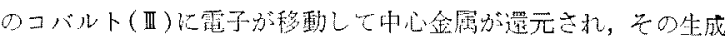

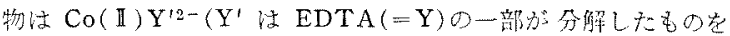

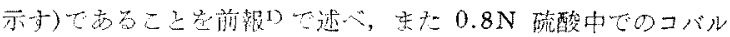

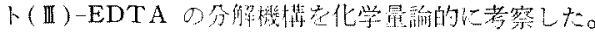

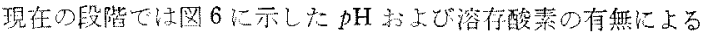

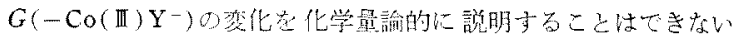

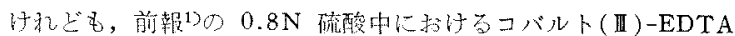

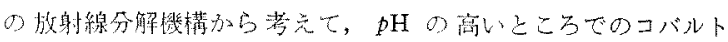

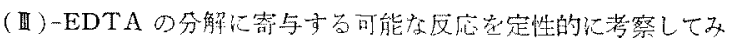
$z_{0}$

酸化性ラシ力ル $\mathrm{OH}$ 法 $p K_{a} \sim 10^{3) 4}$ であるから $p \mathrm{H}$ の非常に

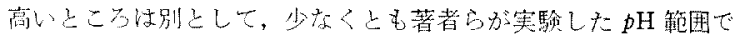

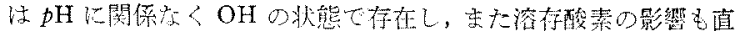

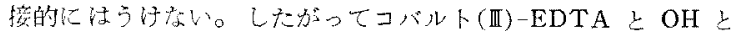

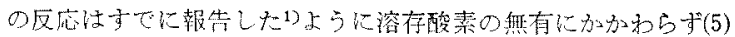
式の反応起子ので，ここで問題になるのは邆元性ラジカルて， これが溶存酸素の有热化よる $G\left(-\mathrm{Co}\right.$ (II) $\mathrm{Y}^{-}$)の差のおむな原因 と考えられる。

$$
\mathrm{Co}\left(\text { II) } \mathrm{Y}^{-}+\mathrm{OH} \longrightarrow \mathrm{Co} \text { (II) } \mathrm{Y}^{\prime 2-}+\mathrm{H}_{2} \mathrm{O}\right.
$$

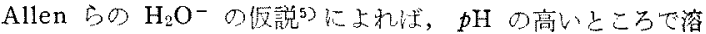

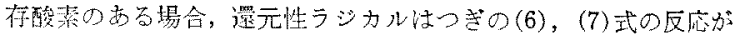
起方。

$$
\begin{aligned}
& \mathrm{H}_{2} \mathrm{O}^{-}+\mathrm{O}_{2} \longrightarrow \mathrm{O}_{2}^{-}+\mathrm{H}_{2} \mathrm{O} \\
& \mathrm{H}^{+}+\mathrm{O}_{2}^{-} \rightleftarrows \mathrm{HO}_{2}
\end{aligned}
$$

pH の低いところでは $\mathrm{H}_{2} \mathrm{O}^{-}$注(8)，(9)式の反応により， $\mathrm{HO}_{2}$

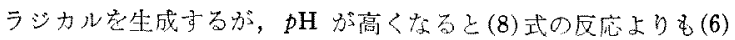
武の反応が起りやすく架るために $\mathrm{O}_{2}{ }^{-}$ダ生成し, これが $\mathrm{H}^{+}$と (7) 式の上5\%平衡状態定つくる。

3) M. Koulkes, Compt. rend. 246, 1203(1958).

4) "Comparatiue Effects of Radiation" Edited by M. Burton, J S. Kirby-Smith, J. L. Magee, Writtem by C. J. Hochenadel (1960)p. 151 .

5) Andries Hummel, A. O. Allen, Radiation Research 12, 302 (1962). 


$$
\begin{aligned}
& \mathrm{H}_{2} \mathrm{O}^{-}+\mathrm{H}^{+} \longrightarrow \mathrm{H}_{2} \mathrm{O}+\mathrm{H} \\
& \mathrm{H}+\mathrm{O}_{2} \longrightarrow \mathrm{HO}_{2}
\end{aligned}
$$

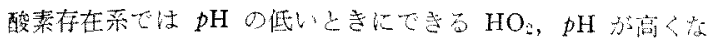
ってできる $\mathrm{O}^{-}$はともにつき゚(10)，(11)式りように2 分子消 堿反応放起方。

$$
\begin{aligned}
& \mathrm{HO}_{2}+\mathrm{HO}_{2} \longrightarrow \mathrm{H}_{3} \mathrm{O}_{2}+\mathrm{O}_{2} \\
& \mathrm{O}_{2}^{-}+\mathrm{O}_{2}^{-} \stackrel{2 \mathrm{H}_{2} \mathrm{O}}{\longrightarrow} \mathrm{H}_{2} \mathrm{O}_{2}+\mathrm{O}_{2}+2 \mathrm{OH}^{-}
\end{aligned}
$$

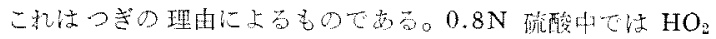

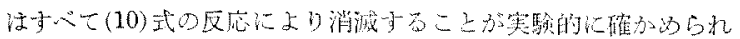

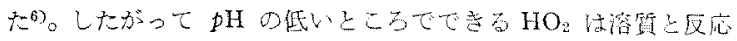

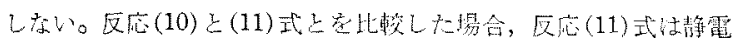

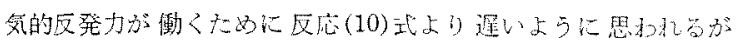

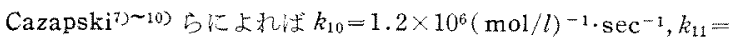

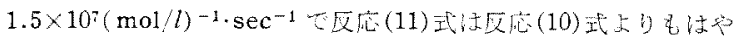

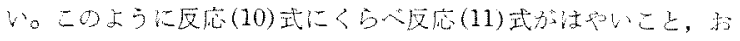

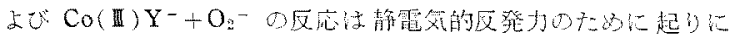

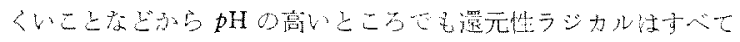

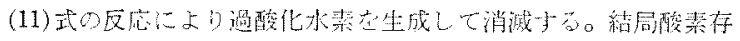

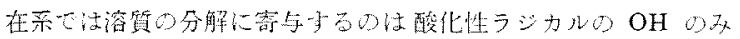

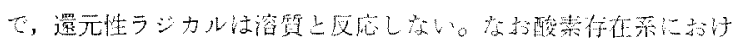

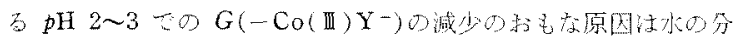

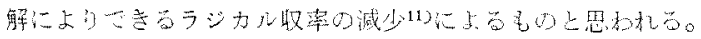

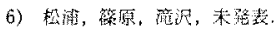

7) G. Cazapski, L. M. Dorbman, J. Phys, Chcm. 68, 1169(1964)

8) G. Cazapski, B. H. J. Bielski, ibid. 67, 2180(1963).

9) J. H. Baxendale, Radiation Research 17, 312(1963).

10) B. H. J. Bielski, E. Saito, J. Phys. Chen. 66, 2266(1962).

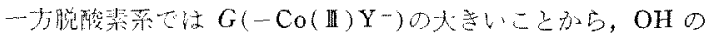

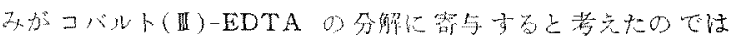

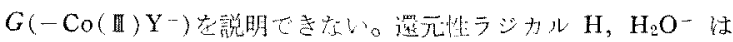

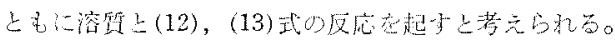

$$
\begin{aligned}
& \mathrm{Co} \text { (II) } \mathrm{Y}^{-}+\mathrm{H} \longrightarrow \mathrm{Co}(\mathbb{I}) \mathrm{Y}^{\prime 2-}+\mathrm{H}_{2} \\
& \mathrm{Co}(\text { II }) \mathrm{Y}^{-}+\mathrm{H}_{2} \mathrm{O}^{-} \longrightarrow \mathrm{Co}(\text { II }) \mathrm{Y}^{2-}+\mathrm{H}_{2} \mathrm{O}
\end{aligned}
$$

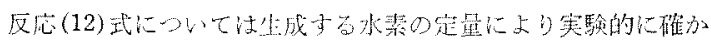

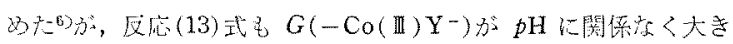

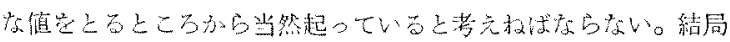

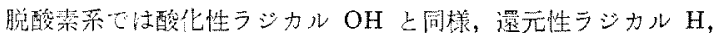
$\mathrm{H}_{2} \mathrm{O}^{-}$もコバルト(II)-EDTA 忞分船する。

$p \mathrm{H}<3 て p \mathrm{H}$ の增加と已もに水小らのラジカル収率け減少与

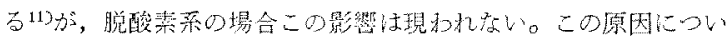

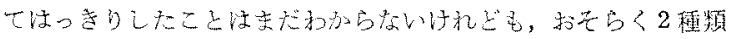

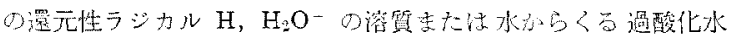

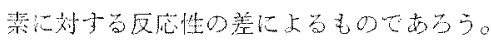

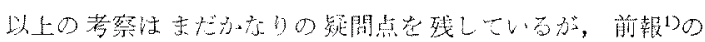

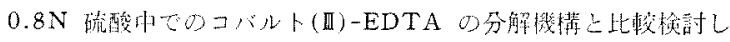

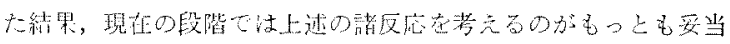

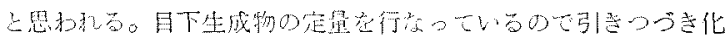

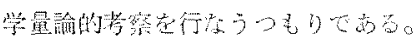

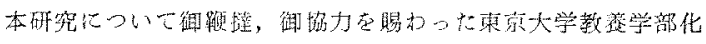

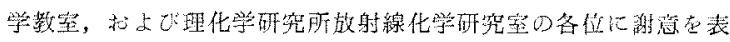
す。

11) A. O. Allen, "The Radiation Chemistry of Water and Aqueous Solution" D. Van Nostrand Company, Inc. (1961) p. 47.

\section{ピロリン酸の存在下における鉄 $(\mathrm{II})$ 溶液の自動酸化}

(明和 40 牦 2 月 2 日造理)

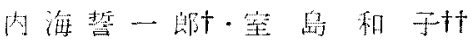

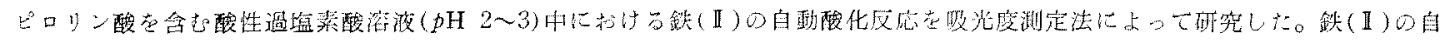

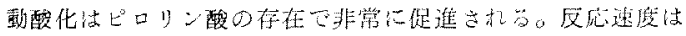

$-\mathrm{d}[\mathrm{Fe}(\mathbb{I})] / \mathrm{d} t=k(\mathrm{Fe}(\mathbb{I}))\left(\mathrm{H}_{2} \mathrm{P}_{2} \mathrm{O}_{7}^{2-}\right)\left(\mathrm{O}_{2}\right)$

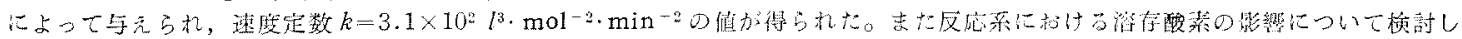

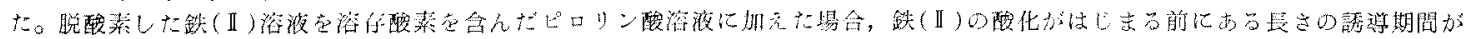

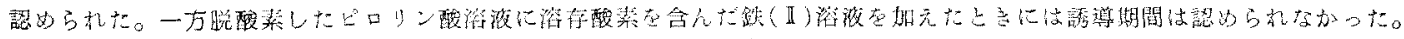

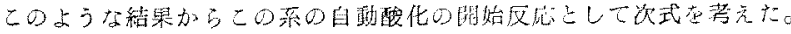

$\mathrm{Fe}($ II $)-\mathrm{O}_{2}+\mathrm{pp}+\mathrm{H}^{+} \longrightarrow \mathrm{Fe}(\mathrm{II})-\mathrm{pp}+\mathrm{HO}_{2}$

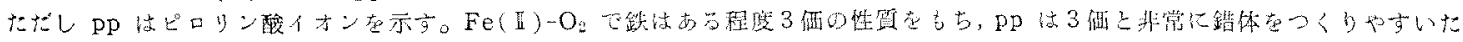

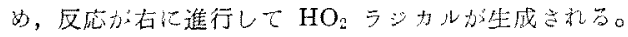

\section{1 緒 㲷}

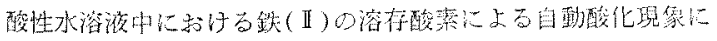

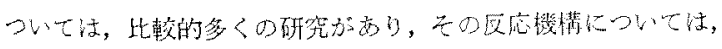

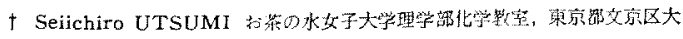
场町

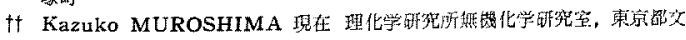

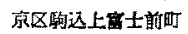

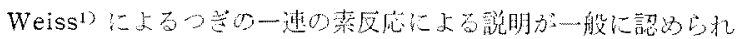
rw:

$$
\begin{aligned}
& \mathrm{Fe}(\mathbb{I})+\mathrm{O}_{2}+\mathrm{H}^{+} \longrightarrow \mathrm{Fe}(\mathbb{I I})+\mathrm{HO}_{2} \\
& \mathrm{Fe}(\mathbb{I})+\mathrm{HO}_{2}+\mathrm{H}^{+} \longrightarrow \mathrm{Fe}(\mathbb{I})+\mathrm{H}_{2} \mathrm{O}_{2} \\
& \mathrm{Fe}(\mathbb{I})+\mathrm{H}_{2} \mathrm{O}_{2}+\mathrm{H}^{+} \longrightarrow \mathrm{Fe}(\mathbb{I})+\mathrm{H}_{2} \mathrm{O}+\mathrm{OH}
\end{aligned}
$$

1) J. Weiss, J. chim. phys. 48, C-6(1951). 